\title{
Wagnerian Myth Through The Mirror of Satirical Iconography
}

\author{
${ }^{1}$ Aigul A. Vasilova, ${ }^{2}$ Askar N. Mustafin, ${ }^{3}$ Aleksandr V. Morozov \\ ${ }^{1,2}$ Kazan Federal University, Institute of Management, Economics and Finance, Assistant Lecturer of the \\ Department of the Economic Theory, ${ }^{3}$ Kazan National Research Technological University, Candidate of \\ Economic Sciences, Associate Professor of the Department of the Economy,
} Email:*mustafin.ksu@yandex.ru, sneg1221@mail.ru

\section{Received: 15th December 2017, Accepted: 20th December 2017, Published: 31st December 2017}

\begin{abstract}
A personal satirical iconography is a valuable source of information about composers. Developing under the influence of many factors - public opinion, private and professional reputation, friendly or hostile relations with critics and artists - it complements pure facts of musician biographies and analytical materials with an emotionally colored perception. The article examines the satirical images of Richard Wagner, which reflect the peculiarities of the approach to his personality and creativity: internationalism, accentuated publicism, grotesque, denunciation and prolongation to the future. Wagner's iconography was created by the caricaturists of different countries and peoples for a long time. In different periods, the perception of the German composer as a person and an artist was supplemented by new nuances, mostly of negative character. Thus, "Wagnerian myth" appeared in the world of caricature, interpreting its creative path as a chain of annoying delusions and insidious atrocities that had long-term negative consequences in musical art and world history. The composer is shown as a vain and an arrogant man, obsessed with his power delusions, a self-interested person, a demonic personality, the destroyer of classical orchestra standards. In recent decades, there has been the tendency of Wagner's personality "rehabilitation" in a caricature, the perception of his heritage as a stable element of the world musical culture in all the complexity of its components.
\end{abstract}

Keywords: Wagner, Musical Iconography, the Satire of Images, Caricature, Music.

\section{Introduction}

Richard Wagner is one of the most controversial figures of musical art and he served as a favorite "target" for caricaturists not only throughout his creative path, but also after death. Different facets of his artistic nature, different works and ideals were in the focus of artist attention. And until now the objects of Wagner's heritage make an ambiguous reaction of the public periodically, becoming an occasion for a heated discussion in society - whether it is the fate of the Bayreuth Festival or the performance of his opera works.

\begin{abstract}
Methods
The study uses the descriptive method with its components: observation, interpretation and generalization; biographical and system-historical methods of musical historical research; historicalfunctional method. The specificity of interdisciplinary research related to the study of poly code texts, led to the use of iconographic and iconological, contextual and semantic-stylistic methods of analysis. Theoretical basis was represented by the works on the theory and the history of the caricatures by A.S. Ainutdinov [1]; A.M. Arias [2]; A.G. Golikov [3]; A. Nael [4]; K. Greth [5]; L.G. Safiullina, R.R. Rakhmatullina, L.I. Salikhova, G.I. Batyrshina [6; 7], I. Krissoshoidis [8], where a caricature is studied from philosophicalaesthetic, semiotic, linguistic positions as an graphic and verbal text.
\end{abstract}

\section{Results}

Richard Wagner is a controversial and even an odious figure in the musical art: a famous composer and a literary figure; a deep thinker and the author of provocative statements; a talented producer, who had an extraordinary gift of persuasion and the pioneer of the opera festival movement. Being an idol of millions, he had a powerful impact not only on German composer school, but also on all European music. Providing truly revolutionary ideas ahead of his time, Wagner became an object of sharp critical attacks, which did not cease during his life and many years later.

His unique position in musical satire of images is ensured, first of all, by its international status. Unlike other composers who were interesting to fellow journalists, Wagner became the aim of caricatures by German, French, Austrian, English, Italians, Russians, Poles. This is explained by the fact that Wagner has overcome the limits of his national school, numerous followers from other countries followed him. The desire to preserve an ethniccultural identity in music prompted critics to oppose the dominance of Wagner's concepts. This movement was particularly pronounced in France, which has been studied in numerous studies $[9 ; 10$; 11; 12]. Secondly, it is explained by an unprecedented relevance: each new generation found something in Wagner's music, literary heritage, personality that required a critical response. Time passed, targets changed, the things that 
previously seemed unacceptable, were understood and sometimes assimilated (this concerns his musical innovations). But the need for the composer condemnation, the flagellation of his inherent defects and flaws, remained unchanged. This is largely due to the political situation in Europe, which was plunged into the bloodshed of the Second World War during the 1930-ies and 1940-ies. A bitter experience, taken from the "experiments" of world domination achievement by a single people, held under Wagner's music, left an imprint on its perception. The nationalistic utterances of the composer, made in the previous century, became much more acute. Thirdly, by the number of satirical images which cannot be found in the entire history of music. Fourth, by an extraordinary longevity. They continue to create the caricatures of the composer up to now, although their polemical heat is softened in time.

Most of the images clearly illustrates the artists' rejection of the composer's musical and aesthetic platform and his ethical qualities. Caricatures are mostly satirical and even grotesque. Wagner's arrogance and his excessive self-conceit are blamed. Wagner is depicted as the main sculptural decoration of fantastic projects of monuments erected to him in Berlin and Munich, on the pediment of the Paris Opera, eclipsing the musicians-predecessors. The composer's semi-nude torso is barely covered by an antique toga, surrounded by "loud vocals" - a large drum, a trombone and produces a comical impression. Instead of the lyre, he lifts the saw above his head as the main trophy, to which the quacking ducks fly in astonishment. In one of the works he is depicted in the ring of Nibelung, contemptuously looking at his fans worshiping him.

The caricature "Wagner's apotheosis in Bayreuth" depicts the composer in the image of the supreme god of German-Scandinavian mythology Wotan with a baton in his hand, sitting on the throne decorated with notes. His daughters-Valkyries take the bodies of glorious heroes on their horses "fallen" and wounded during the performance of listeners. The theme of Wagner's superiority over authority is developed by the drawing "Wagner, Aeschylus and Shakespeare", based on a historicaltemporal gag. The center of the composition is represented by an arrogant Wagner, surrounded by ancient Greek and English dramatists who bow low to him. Realizing his greatness as a writer (Wagner wrote the libretto for his operas), he graciously accepts "well-deserved" praises from them for his talent. The composer is depicted in the work of the modern Portuguese cartoonist André Carrillo against the background of a stormy sky pierced with powerful rays. Here, the idea of greatness, creative immortality (Wagner looks from heaven) is provided, but without an open mockery of early works.
The artists also showed such Wagner's qualities as enterprise, the ability to provide some financial support of wealthy interlocutors, to convince them of the need to sacrifice large sums for musical projects. Wagner can be called one of the most talented producers of the XIXth century, who is able to promote and implement his bold ideas. Ludwig Bavarian helped the composer to erect a theater building specially designed for his operas, laid the foundations for an authoritative music festival. All these initiatives are still working successfully. However, the art critics of the past were of different opinion, representing Wagner as a person inadequate in his dreams and consumed by an immoderate greed. They painted him walking through a rainbow bridge from the Bayreuth Theater to a madhouse; conducting on a stone with the inscription "Charenton-Bayreuth"1. Often Wagner was pictured in the form of a beggar, circumventing fellow citizens with a worn suitcase on which the "Music of the Future" was written; reverently pounding at the door of the ticket office; bent in half anticipating a handout; "A wealthy traveler with 8,000 thalers received from sponsors." In another figure, Wagner requires the publisher to buy a stack of his operatic works with a threat. The alligator with an open mouth stands behind Wagner. The animal is ready to bite the wavering owner of the printing business in case of refusal.

The images of King Ludwig II of Bavaria, Wagner's ardent admirer and generous contributor, are also not accidental ones. On the lithography "King Lohengrin" of 1885, he is pictured as Wagner's opera character in a boat pulled by swans, with a harp in his hands. Ludwig-Lohengrin floats in ghostlyenticing light of the crescent moon, in which the profile of the German composer can be seen.

The financial theme is also discussed after Wagner's death, in connection with the fate of the Bayreuth festival. One of the caricatures pictured a grocery store, filled with vessels of all shapes and sizes and pharmacy scales. According to the signature, they sell "Wagner's spiritual heritage" here. The composer's widow Cosima, the director of the Bayreuth festival, is pictured as a saleswoman; her son Siegfried helps her, pouring out a miraculous potion. There is also a visitor in the shop, Herr Michael $^{2}$, who is offered a "commodity": "It's a great pity, Herr Michael, but we do not have much parsifal left; but I can offer you Tannhäusers and fresh Dutchmen". The vessel on the right has the following note: "The ripper of bear skins". It's the hint at the true goals of the shop owners (to rob customers completely). On the next figure, Cosima dances with Uncle $\mathrm{Sam}^{3}$, trying to "shake out" money for the festival from the wealthy American. Cosima together with Ludwig can be seen on the picture "The Ride of the Valkyries", with a banner and arms in hands defending Wagner's ideas. She is 
also shown on the caricature where Jupiter submits to Wagner, hearing the sounds of his big drum. Cosima is pictured sitting on the ground behind her husband, collecting into her apron money rain pouring from the sky, caused by Wagner's thunderous music.

The orchestra theme is one of the most common in caricatures about Wagner. According to them, the contemporaries perceived his orchestral style as too loud and monotonously sounding. Here Wagner with protruding eyes gives a sadistic "blow in the ear" with a hammer and an awl. Here he marches with a big drum, vigorously striking it with giant mallets. The same composition is repeated by the caricature "Tannhauser" by the French artist Gilles Blass, accompanied by the commentary "Wagner is the inventor of a big drum" [13]. Here Wagner tries to perform his melodies using kitchen utensils. Percussion instruments mourn over Wagner's death bitterly: bass and snare drums, timpani, and cymbals. Wagner is also shown as an infernal character: performing the overture "Faust", he is able to raise the listeners in the air by the force of a sound. The palette of his conducting gestures is wide: flexible swings with his hands-wings, prickly strikes with the baton over tangled musical notes and keys; quite "peaceful" dance moves.

Often, Wagner is treated by cartoonists as a conqueror, intruding into another's musical world. Blass creates several works on this topic, forming in a cycle: "Wagner, examining Paris in a telescope", "The transfer of Tannhauser to Paris". This theme is continued in the cartoon "The Siege of Paris by Wagner" by B. Moloch, where the followers of the composer - the conductor Charles Lyamureu and the director of the Paris Opera Pedro Gayar attack the city with deafening trumpet sounds.

Often Wagner appears on paired portraits: with the critic Eduard Hanslik, an ardent anti-Wagnerian, severely chastising the composer; with Hector Berlioz, who takes part of his fame; with Anton Bruckner who worshiped him; friendly List; the singer Amalia Materna, who became famous for her interpretation of Brunnhilde.

The caricatures of Georges Tire-Bone of the late 19th century depicted the confrontation between Berlioz and Wagner in Paris. On one of them, the French composer is portrayed riding a white ornate horse (the comparison with the "Trojan horse") hovering over the city, and Wagner is pictured storming the pedestal with a rope ladder tied to the top of the Opera Garnier. The inscription in the upper corner of the picture reads: "Divine patrons of the eternal city" (quote from the Berlioz dilogy "Trojans", written on the motives of the "Aeneid" by Virgil). Thus, the artist raises the issue of the musical drama similarity and difference by Berlioz and Wagner - two outstanding reformers of the opera house. Another drawing, entitled "Wagner's triumph", shows Berlioz on the foreground: his hands are in pockets, his face expresses melancholy. The jubilant crowd throws Wagner into the air on the background.

The result of the polemics between Wagner and Hanslick is shown in the silhouette "Wagner and Viennese critics", where Wagner is surrounded by tiny figures of men threatening him, and in the cartoon "Wagner triumphs over Jewish theater critics after the performance", where he travels in a wagon, urging masters of the pen submissively walking after him by scourge. As we see Wagner's unseemly anti-Semitic position was also reflected in the imaging satire, and not just in a single manifestation. The composer is shown both in the circle of Jewish children, and among the Jewish audience at the concert, as well as in a series of images with a shofar.

Years later, this topic was developed in the caricatures by Arthur Jic from the Second World War. They have an angry accusatory pathos. Wagner, playing the piano, is surrounded by German commanders. Inspired by his sounds, they gather in columns under swastika banners and go to destroy all life. The tank, the airplane, and the lines of marching soldiers are braided with a fine sound lace. On another cartoon, we see Hitler in the image of Lohengrin, fully armed. Hitler is perplexed and depressed. The outlines of a Soviet soldier with a five-pointed star on a helmet appear on the background. The drawing is accompanied by the following signature: "To Lohengrin. The wolf, who, thinking of climbing into a sheepfold, fell on the kennel". These charges have some ground. It is known that Hitler was fascinated by Wagner's music and his nationalistic ideas, and the performances of the Bayreuth festival were eagerly visited by the tops of the Third Reich. However, a direct relationship between Wagner's art and the ideology of fascism is a mistake. These drawings can be attributed to a rare type of political music caricatures, tracing the connection between musical phenomena and a political situation. A similar pamphlet on Wagner was created by a contemporary Slovak artist Marian Kamensky. He expresses the idea of enchanting sound danger, which develop both the creative ideas of Ludwig of Bavaria, and an "ordinary fascism" of Hitler. The author forces to think once again about the artist's responsibility to society, about a high ethical mission of a musician-thinker.

The counterpoint of goodwill is the silhouettes of the Austrian artist Otto Böhler, who "repetitively" recreate the meeting between Wagner and Bruckner in Bayreuth, when the latter asked his idol to take the dedication of one of his symphonies. Wagner gave preference to the Third Symphony, and addressed the admirer by a flattering comparison with Beethoven. Böhler is also supported by the Russian cartoonist Yuri Prozhoga, who says: "Wagner is the 
best!" The name of the German composer and of the Brazilian football player (Wagner Lava) is used in his work. The drawing is accompanied by a direct speech of the heroes: "I play Tannhauser" (thesis), "I play in TCSKA" (antithesis) and by the conclusion (synthesis): "All Wagners play well."

\section{Discussion}

Wagner's satirical iconography is extensive, but tendentious. The bulk of the cartoons contains a satirical and a grotesque intention, linking Wagner's activities with the destruction of unshakable musical foundations, the invasion of the national specifics, the implementation of ambitious projects. Artists blame the composer for the lack of humanistic orientation of works, the lack of warmth and kindness, and blame him for social cataclysms that occurred half a century later.

\section{Conclusions}

The satiric images examined by us show Wagner in a sharp satirical and grotesque vein as a proud man, a greedy man and an anti-Semite. His position is unstable: between triumph and failure, fame and oblivion, talent and mediocrity. Later, Wagner was also accused of pro-fascist sentiments development in Germany that led the country to humanitarian and cultural catastrophe in the 1930s and 1940s. A German romanticist emerges as a demonic personality associated with the world of evil and darkness.

Wagner's iconography was created by the caricaturists of different countries and peoples for a long time. In different periods, the perception of the German composer as a person and an artist was supplemented by new nuances, mostly of negative character. In recent decades, there has been the tendency to "rehabilitate" Wagner's personality in a caricature, to perceive his heritage as a stable element of the world musical culture. Wagner's caricatures are characterized by open publicism and an accusatory tone as a rule.

The results of the study will contribute to the deepening of the existing knowledge about the change of stylistic paradigms in the history of music in their interconnection with related art forms, the spiritual climate of the epoch, as well as with public opinion and perceptions. At the same time, the ideas are developed about the thematic and species diversity of a caricature interpreting the phenomena of musical creativity.

\section{Acknowledgements}

The work is performed according to the Russian Government Program of Competitive Growth of Kazan Federal University.

\section{References}

1. Aynutdinov A.S. Caricature as a type of comic intent picturing in modern Russian print media: abstract from dis. written by the cand. of philology. - Ekaterinburg, 2010. - 20 p.

2. Arias A.M. Interaction of a verbal and a nonverbal component in a cartoon and a collage: the material of the German-language media: the author's abstract from the dis. by the cand. of philology. - St. Petersburg, 2012. - 30 p.

3. Golikov A.G., Rybachenok I.S. Laughter is a serious matter. Russia and the world at the turn of the XIX-XX centuries in a political caricature. - M., 2010. - $328 \mathrm{p}$.

4. Nael A. Tragic in a cartoon: on the material of cartoons from Estonian editions of the interwar period (1918-1940) // Russian philology. Issue 25. Tartu, 2013. - pp. 274 - 283.

5. Greth K. Le dessin de caricature en Russie comme miroir des representations: memoire de DEA. - Marne la Vallée, 2003.

6. Safiullina L.G., Rakhmatullina R.R. The development of musical satirical iconography: based on the materials of foreign caricatures of the XVIIIth - early XIXth centuries. // Bulletin of the South Ural State University. Series: Humanities. 2016. - V. 16. - No. 2. - pp. 80-89.

7. Salikhova L.I., Safiullina L.G., Batyrshina G.I. Caricature as Means of Visual Communication in Musical Journalism // International Journal of Humanities and Cultural Studies. - 2016. - August. Special Issue. - pp. 233-246.

8. Chrissochoidis I. Handel, Hogarth, Goupy: artistic intersections in early Georgian England // Early Music: Oxford Journals. - 2009. - Volume 37, Issue 4. - pp. 577-596.

9. Wagner et la France: Numero special de la Revue musicale. - Paris, octobre 1893.

10. D'Indy V. Richard Wagner et son enfluence sur l'art musical francaise. - Librairie Delayrane. Paris, 1930.

11. Huebner S. French opera at the fin de siècle. Wagnerism, nationalism, and style. - Oxford, 1999. $-526 \mathrm{p}$.

12. Tashtamirova L.Sh. Wagner and France. Wagner's influence on the French culture of the second half of the XIXth century. - M., 2013. - 155 p.

13. Grand-Carteret J. Richard Wagner en caricatures. - Paris, 1892.- 336 p.

\section{Footnotes}

${ }^{1}$ Charenton is the name of a psychiatric hospital in the vicinity of Paris.

${ }^{2}$ This is the collective name of an ordinary German.

${ }^{3}$ The collective name of an ordinary American. 